\title{
Tricuspid valve endocarditis in a drug addict: will two operations do?
}

\author{
Pavel Žáček', Jan Dominik', Jan Harrer'1, Jan Vojáček', Miroslav Solař² \\ 'Department of Cardiac Surgery, The Cardiocentre, University Hospital Hradec Králové and Faculty of Medicine in Hradec Králové, \\ Charles University in Prague, Hradec Králové, \\ ${ }^{2}$ First Department of Internal Medicine, University Hospital Hradec Králové and Faculty of Medicine in Hradec Králové, Charles \\ University in Prague, Hradec Králové, Czech Republic
}

Žáček P, Dominik J, Harrer J, et al. Tricuspid valve endocarditis in a drug addict: will two operations do? Cor Vasa 2010;52:362-364.

A case of tricuspid valve endocarditis in a young drug addict is described which was treated surgically by valve replacement. Failure to stop intravenous drug abuse led to early destruction of the implanted bioprosthesis in a new onset of prosthetic valve endocarditis. A comparison of the operative findings at the initial operation and reoperation underlines the difficulties in the treatment of infective endocarditis in intravenous drug addicts. Different treatment strategies are discussed.

Key words: Tricuspid valve - Endocarditis - Drug abuse - Surgery

Žáček P, Dominik J, Harrer J, et al. Trikuspidální endokarditida u toxikomana: budou dvě operace stačit? Cor Vasa 2010;52:362-364.

V kasuistice je popsán př́pad endokarditidy na trikuspidální chlopni u mladého toxikomana, která byla řešena náhradou chlopně. Při pokračování v intravenózní aplikaci drog došlo k časné destrukci implantované bioprotézy v důsledku nové ataky protézové endokarditidy. Srovnání operačního nálezu při první operaci a reoperaci dokumentuje úskalí léčby infekční endokarditidy u intravenózních toxikomanů. $\checkmark$ diskusi jsou probrány možné léčebné postupy.

Klíčová slova: Trikuspidální chlopeň - Endokarditida - Drogová závislost - Operace

Address: Assoc. Prof. Pavel Žáček, M.D., Ph.D., Department of Cardiac Surgery, The Cardiocentre, The Cardiocentre, University Hospital Hradec Králové and Faculty of Medicine in Hradec Králové, Charles University in Prague, Sokolská 581, 50005 Hradec Králové, Czech Republic, e-mail: zacek@fnhk.cz

\section{Case report}

A 27-year-old male, an intravenous pervitine addict, was diagnosed with infective endocarditis of the tricuspid valve. Staphylococcus aureus was repeatedly isolated in blood cultures. Multiple pulmonary septic emboli were identified by computed tomography. Conservative treatment with antibiotics for 8 weeks led to a decrease of inflammatory signs; however, severe tricuspid regurgitation due to infective destruction of the valve, right ventricular overload and pulmonary hypertension were documented on echocardiography. On psychiatric examination, the patient denied continuation of drug abuse and proclaimed his firm intention to abstain. At surgery, the damaged tricuspid valve with fenestrations of the septal leaflet and large vegetations was replaced with an Epic SJM 31 bioprosthesis (Figures 1 and 2). The postoperative course was uneventful and patient discharged on the $14^{\text {th }}$ postoperative day.

Fifteen months later, the patient was readmitted for rapid onset of sepsis and dyspnea. He denied drug administration despite the presence of multiple skin puncture wounds and pervitine positivity in urine. Staphylococcus aureus was again the infective agent. Transesophageal echocardiography revealed large vegetations $(21 \times 12 \mathrm{~mm})$ at the bioprosthesis creating severe tricuspid stenosis with a diastolic gradient of $16 \mathrm{mmHg}$. Uncontrollable sepsis and multiple pulmonary embolizations necessitated urgent reoperation. At surgery, massive vegetations were found at the bioprosthesis that virtually obliterated the tricuspid orifice and filled the inlet portion of the right ventricle (Figure 3). The infected bioprosthesis was replaced by a new one (also an Epic SJM 31). The postoperative course was critical due to circulatory shock, right ventricular and respiratory failure requiring extracorporeal membrane oxygenation (7 days), administration of nitric oxide and levosimendan, continuous dialysis. Despite various complications, the patient became gradually stable and, after 2 months at the intensive care unit (ICU), he was transferred to a regional hospital. At out-patient follow-up 5 months later, he was without signs of infections and in NYHA class II. 


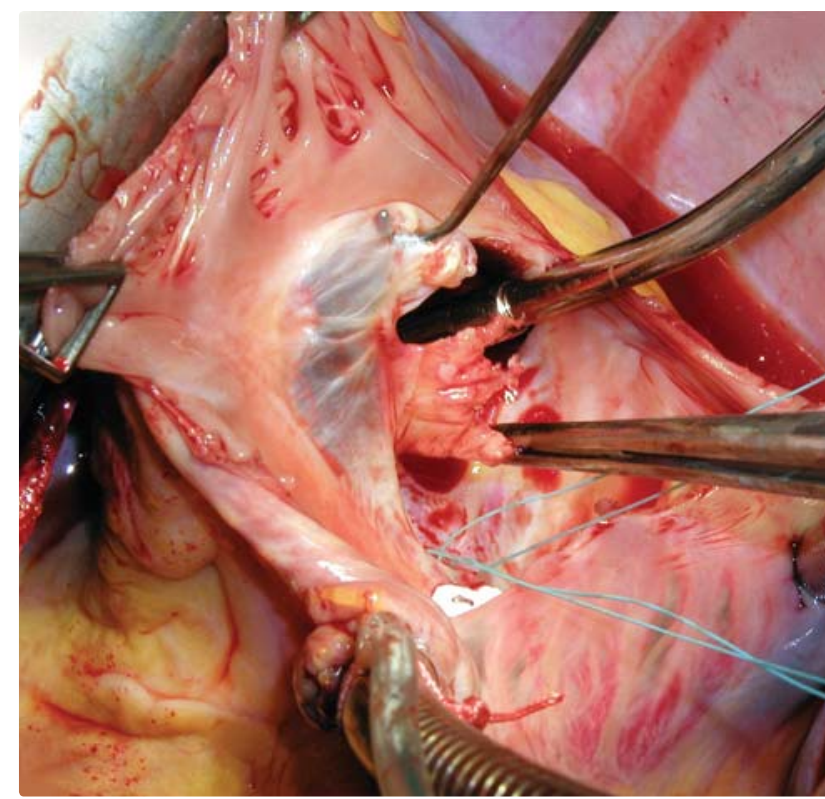

Figure 1 Large vegetations seated at the anterior tricuspid leaflet in native valve endocarditis (primary surgery)

\section{Discussion}

Tricuspid valve endocarditis is a disease typically associated with intravenous drug abuse although it may occur also in connection with right-sided catheterization, pacemaker implantation or congenital heart defects. Its prevalence among injection drug users in urban communities in developed countries has been increasing. ${ }^{1}$ In this patient population, other frequently present medical factors (hepatitis, HIV, nutritional and immunological status), socio-economic status, poor adherence to therapy, and uncertain cessation of addiction affect the final results of treatment.

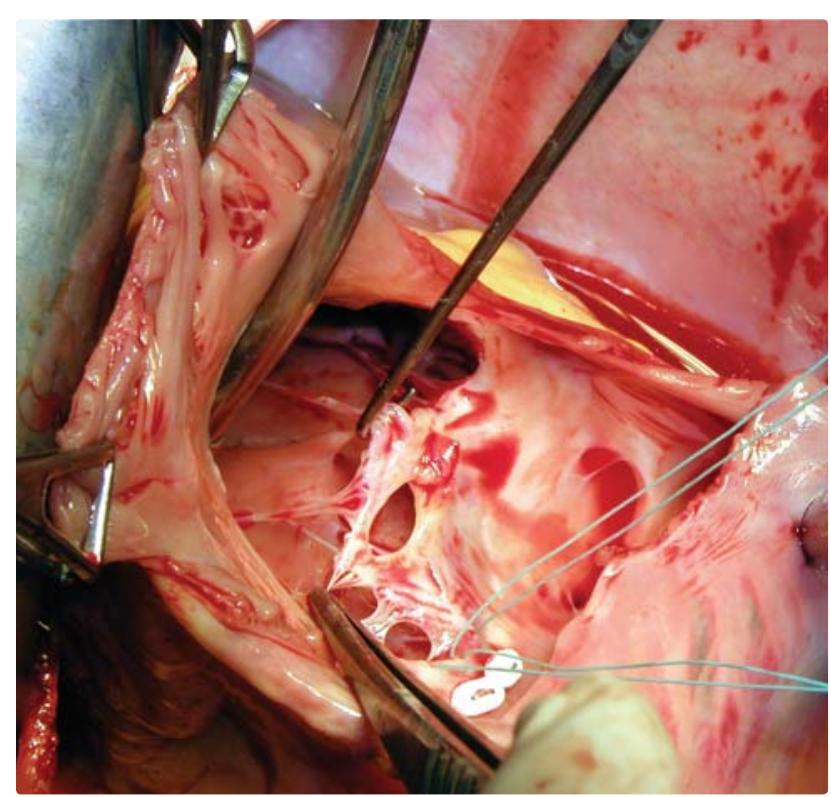

Figure 2 Multiple fenestrations of the septal leaflet resulting from infective destruction (primary surgery)

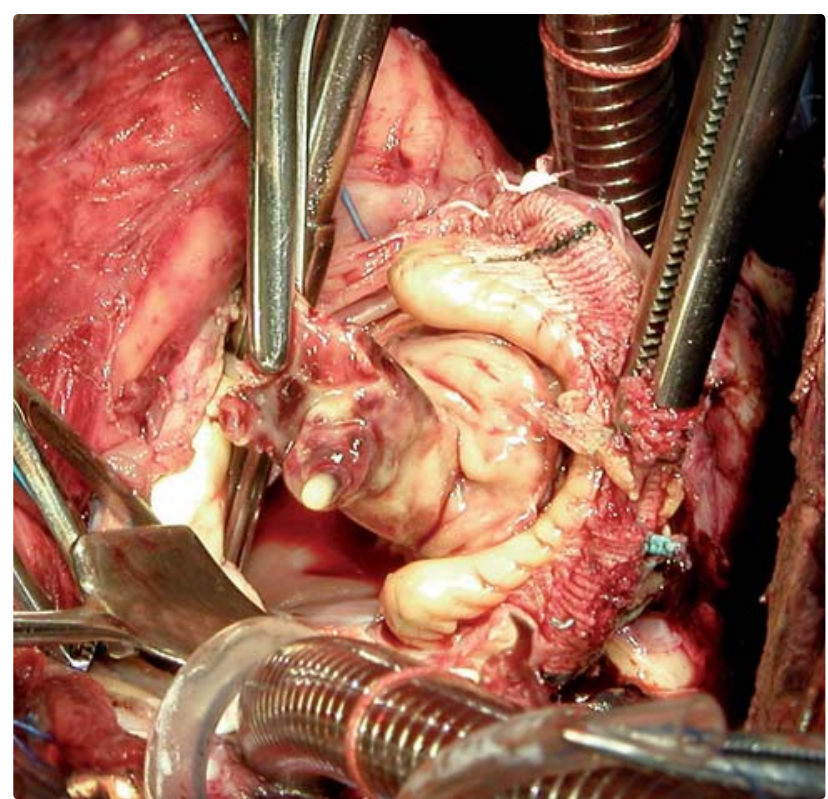

Figure 3 At reoperation, almost complete obliteration of the prosthetic orifice as well as of the inlet portion of the right ventricle due to vegetations was found

The dominant infective agent is Staphylococcus aureus (about 70\% of infections), followed by streptococcal species, Gram negative organisms, fungi or diphteroids. ${ }^{1}$ Clinical manifestations are usually persistent fever, bacteriaemia, and multiple pulmonary emboli. Septic pulmonary emboli may lead to various pulmonary complications which compromise the right heart performance and ultimately result in right heart failure. Topic infective destruction of the tricuspid valve causes tricuspid regurgitation, right-sided volume overload, chamber dilation, and right heart failure. Abscess formation is rare. ${ }^{1-2}$ Supraventricular arrhythmias occur frequently.

Tricuspid valve endocarditis is considered to be a relatively benign disease which responds well to medical treatment in a majority of cases. ${ }^{3}$ Surgical treatment is, however, indicated in uncontrolled sepsis and intractable right heart failure. Large-size vegetations (over $10 \mathrm{~mm}$ in diameter) and recurrent pulmonary embolizations speed up the indication for operation.

At surgery, the principles of removal of all infected tissue and restoration of valve competence have to be balanced with an effort to minimize implantation of foreign material with regard to unpredictable cessation of drug abuse. A reasonable attempt to repair the valve should be undertaken wherever possible. The conservative surgical procedure consists of vegetectomy ${ }^{2}$ together with removal of the infected area of the leaflet. Involvement of a single leaflet only allows for total excision of the posterior leaflet or quadrangular resection of the anterior leaflet. ${ }^{4}$ Multileaflet infective involvement is a contraindication to valve repair. After excision of the infected tissue, valve competency is restored by suture techniques (Kay's bicuspidalization technique ${ }^{5}$ in the case of posterior leaflet resection and De Vega annuloplasty ${ }^{6}$ after partial resection of the anterior leaflet). Autologous pericardium 
may be used for correction of defects or strengthening of the annuloplasty. ${ }^{2}$

Replacement of the valve may be the surgical option if the degree of valve destruction precludes its repair. Regarding choice of the valve for replacement, biological valves are generally preferred though supporting literature data remain controversial. ${ }^{7,8}$ Use of a homograft can also be considered. ${ }^{9,10}$

An alternative strategy is excision of the tricuspid valve without its replacement. The rationale for such an approach is complete avoidance of artificial material in patients continuing their drug abuse and quick accomplishment of the procedure on the beating heart in severely compromised patients. As reported and advocated by Arbulu, ${ }^{11}$ absence of the tricuspid valve can be tolerated quite well although in part of patients treated in such a way, right heart failure may later necessitate valve replacement. ${ }^{12}$

In our case, valve replacement was the only solution due to severe destruction of the valve and presence of pulmonary hypertension which contraindicated mere valve excision. Despite the imperative experience of cardiac surgery and intentions to stop drug abuse, the patient was not able to control his addiction. The resulting prosthetic endocarditis required difficult reoperation followed by a critical postoperative course. In light of the self-inflictive nature of this affection, the economic burden is also of interest. The total hospitalization bill for two cardiac operations in this patient was 2.3 mil. CZK (approx. 80,000 EUR).

\section{References}

1. Moss R, Munt B. Injection drug use and right-sided endocarditis. Heart 2003;89:577-581.

2. Musci M, Siniawski $H$, Pasic M, et al. Surgical treatment of right-sided active infective endocarditis with or without involvement of the left heart: 20-year single center experience. Eur J Cardiothorac Surg 2007;32:118-125.

3. Hecht SR, Berger M. Right-sided endocarditis in intravenous drug users. Prognostic features in 102 episodes. Ann Intern Med 1992;117:560-566.

4. Carozza A, Renzulli A, De Feo $M$, et al. Tricuspid repair for infective endocarditis: clinical and echocardiographic results. Tex Heart Inst J 2001; 28:96-101.

5. Kay JH, Maselli-Campagna G, Tsuji KK. Surgical treatment of tricuspid insufficiency. Ann Surg 1965;162:53-58.

6. De Vega NG. Selective, adjustable and permanent annuloplasty. An original technic for the treatment of tricuspid insufficiency. Rev Esp Cardiol 1972;25:555-556.

7. Munro Al, Jamieson WR, Tyers GF, Germann E. Tricuspid valve replacement: porcine bioprostheses and mechanical prostheses. Ann Thorac Surg 1995;60(2 Suppl):S470-S473; discussion S73-S74.

8. Moon MR, Miller DC, Moore KA, et al. Treatment of endocarditis with valve replacement: the question of tissue versus mechanical prosthesis. Ann Thorac Surg 2001;71:1164-1171.

9. Mestres CA, Castella M, Moreno A, et al. Cryopreserved mitral homograft in the tricuspid position for infective endocarditis: a valve that can be repaired in the long-term (13 years). J Heart Valve Dis 2006;15:389-391.

10. Miyagishima RT, Brumwell ML, Eric Jamieson WR, Munt BI. Tricuspid valve replacement using a cryopreserved mitral homograft. Surgical technique and initial results. J Heart Valve Dis 2000;9:805-808; discussion 808-809.

11. Arbulu A, Holmes RJ, Asfaw I. Surgical treatment of intractable right-sided infective endocarditis in drug addicts: 25 years experience. J Heart Valve Dis 1993;2:129-137; discussion 138-139.

12. Robin E, Thomas NW, Arbulu A, et al. Hemodynamic consequences of total removal of the tricuspid valve without prosthetic replacement. Am J Cardiol 1975;35:481-486.

Received 19. 3. 2010 